\title{
Det glemte folk tjerkesserne er ved at blive synligt igen
}

Lars Funch Hansen

\section{0-året for Tsarruslands fordrivelse af tjerkesser- ne og vinter-OL i Sotji ventes at styrke deres inter- nationale synlighed. I Nordkaukasus lever de i de vestlige republikker, Karatjai-Tjerkessien, Kabardi- nien-Balkarien og Adygeja. De kæmper fredeligt for deres sag. Men det kan ændre sig}

I international målestok kan det nordkaukasiske folk tjerkesserne i dag betegnes som et glemt folkeslag, hvilket står i skærende modsætning til situationen i midten af 1800 -tallet. Men i 2014 vil to næsten samtidige begivenheder igen kunne sætte tjerkesserne på en international dagsorden: Dels 150-året for deres fordrivelse efter Ruslands endelige militære sejr og indlemmelse af Tjerkessien i det russisk imperium og dels vinter-OL i Sotji ved den russiske Sortehavskyst, hvorfra de sidste tjerkessere blev udskibet i 1864. I dag findes der mellem tre og seks millioner tjerkessere spredt over adskillige kontinenter - heraf omkring 700.000 i Nordkauasus.

I de senere år er skabt en række nye tjerkessiske organisationer, som arbejder for at bevidstgøre og mobilisere tjerkessere omkring deres egen historie og identitet og promovere internationalt samarbejde blandt tjerkessiske organisationer. Der er ligeledes i de seneste år sket en mangedobling af antallet af tjerkessiske internet-initiativer, som medvirker til at øge tjerkessernes synlighed og fællesskabsfølelse. Det bringer mindelser om 1800-tallet, hvor aviserne i en række lande fulgte med i tjerkessernes kamp mod Ruslands kolonisering af området, blot med den forskel at tjerkesserne nu selv i langt højere grad deltager i formuleringen af tjerkessisk historie og identitet.

Når især Vesten i 1800-tallet fulgte 
med i tjerkessernes kamp mod Rusland - og i et vist omfang også støttede deres kamp - skyldtes det primært frygt for, at Rusland skulle bruge Kaukasus som afsæt til indlemmelse af Mellemøsten og i sidste instans endda true juvelen i det britiske imperium: Indien. Trusler som især i Storbritannien blev genstand for mange diskussioner og teorier.

Selve geopolitikkens opståen som begreb og analytisk disciplin skete i forlængelse heraf og konkurrencen mellem Rusland og Storbritannien om indflydelse i området gik under betegnelsen 'the Great Game'. Selv om tjerkesserne i nutiden kun findes i lommer i deres gamle hjemland og som sådan ikke umiddelbart udgør en separatistisk trussel, så har området alligevel opnået fornyet geopolitisk interesse, da det efter Sovjetunionens sammenbrud igen blev til en grænsezone.

\section{Broderfolk med abkhaserne}

Det blev understreget af Ruslands krig med Georgien i 2008 og den efterfølgende anerkendelse af det tilgrænsende Abkhasien som selvstændigt land. Tjerkesserne opfatter abkhaserne som deres broderfolk, og hundredvis af tjerkessere deltog som frivillige i krigen mod Georgien i 1992-1993.

I Nordkaukasus findes tjerkesserne primært i de tre vestligste republikker: som titelnation i KaratjaiTjerkessien (KTR), i Kabardinien-
Balkarien (KBR) og i Adygeja (AR).

Balkarerne og karatjaierne er to indbyrdes tæt beslægtede tyrkisktalende folkeslag, som især er bosat i de sydligste bjergrige egne af de to førstnævnte republikker. Dobbeltnationsrepublikkerne er et levn fra fortidens sovjetiske nationalitetspolitik i det nordlige Kaukasus. På den ene side opnåede disse etniske grupper en formel etnisk-territorial anerkendelse med dertil hørende rettigheder til brug af eget sprog i politiske og kulturelle sammenhænge - og ikke mindst i skolesystemet.

På den anden side var sammensætningen af republikkerne også et udtryk for den del-og-hersk tilgang, som var en væsentlig del af den leninistisk-stalinistiske nationalitetspolitik, hvor man allerede i de tidlige år af Sovjetunionens eksistens søgte at stække nationalisme og etnisk mobilisering ved ikke at sammensætte de nært beslægtede folkeslag i fælles republikker. I KBR udgør kabarderne nu flertallet med godt 55 pct. af befolkningen, mens balkarerne udgør omkring 11 pct. I KTR er tjerkesserne i mindretal med 11 pct., karatjaierne udgør ca. 38 pct. og russerne ca. 34 pct. I AR udgør adygerne et mindretal på godt 24 pct. og russere knap 65 pct. med begge sprog som officielle sprog i republikken. Der findes yderligere omkring 20.000 tjerkessere ved Sortehavskysten i Krasnodar Regionen og et ukendt antal i Moskva og andre russiske storbyer. Den 
procentvise andel af tjerkessere er stigende i de tre her omtalte republikker, som således også er ramt af de samme etniske homogeniseringsprocesser som resten af Nordkaukasus.

\section{Tjerkessien som førmoderne stat}

Tjerkesserne er et indfødt kaukasisk folk og deres sprog tilhører - sammen med abkhasernes - den nordvestkaukasiske sproggruppe. Tjerkessere kan i regionen spores tilbage til 1300-tallet, men har rødder som muligvis rækker flere tusind år tilbage. Tjerkessien kan, som en førmoderne stat delvis uden præcise grænser, findes på en lang række landkort fra 1500-tallet op til 1800tallet, hvorefter området ikke blot blev russisk, men i mange tilfælde også blev ændret fra at tilhøre Asien til nu at tilhøre Europa. Disse kort er blevet genoptrykt utallige gange efter Sovjetunionens opløsning.

I diasporaen anslås der at findes mellem to og fem millioner tjerkessere. Tallene er uvisse pga. manglende statistikker især i Tyrkiet, hvor man regner med, at mindst seks-syv millioner er af kaukasisk afstamning. I Tyrkiet findes over to hundrede tjerkessiske landsbyer, hvoraf hovedparten er lokaliseret på den anatolske højslette. Usikkerheden om tallene skyldes også, at betegnelsen tjerkesser i Tyrkiet ofte er blevet brugt om alle migranter fra Kaukasus, især Nordkaukasus. Først efter
Sovjetunionens sammenbrud og efterfølgende krige i Abkhasien og Tjetjenien begyndte der at ske en vis udskilning og etablering af nye etnisk definerede kaukasiske grupperinger. Men man finder stadig fx tjetjenere og abkhasere som aktive $\mathrm{i}$ tjerkessiske foreninger og organisationer, hvor de dog sjældent udgør mere end 10-20 pct.

Dette er dels et udtryk for en fælles kaukasisk solidaritet blandt folkeslag som besidder flere kulturelle fællestræk og har fælles historie i eksil. Og dels en praktisk anordning i områder, hvor der ikke er folk nok til at etablere en etnisk-defineret forening. Både i Rusland og i Vesten blev betegnelsen 'tjerkesser' tilbage i 1800-tallet ofte anvendt som fællesbetegnelse for de kaukasiske bjergfolk, som gennem mange årtier opnåede en mytologisk status i Vesten for deres kamp mod Rusland. Den tjerkessiske diaspora findes ydermere i Mellemøsten, som følge af territoriale udvisninger i 1800-tallet under det Osmanniske Rige, i Vesteuropa især som gæstearbejdere fra Tyrkiet eller efterkommere heraf og i USA især pga. flytninger af hele landsbyer fra Golan-højderne, efter at krigen i 1967 gjorde dem til flygtninge.

\section{Nordkaukasus efter 1991}

Som i resten af Sovjetunionen opstod der også blandt tjerkesserne nationale bevægelser omkring slutnin- 
gen af Glasnost-perioden og efter Sovjetunionens sammenbrud. Perioden var præget af etnisk renæssance og Adyge Hasa blev den centrale organisation, nye medier opstod og mange nye publikationer om tjerkessisk historie og identitet blev udgivet. Adyge Hasa organiserede både militær og humanitær støtte til Abkhasiens militære kamp mod Georgien fra 1992, hvilket medførte at Adyge Hasa var på nippet til at komme til magten i KBR.

I dag er veteraner fra krigen i Abkhasien stadig en indflydelsesrig gruppe og deres organisation den største NGO i republikken. Som et modsvar og som et forsøg på at dæmme op for diaspora-promoveret nationalisme støttede Kreml etableringen af en international forening af tjerkessere (ICA) - primært som et forsøg på at kvæle nye initiativer, minimere internationalt samarbejde og helst kun tillade udveksling af dans og musik. I 2000 tiltvang de lokale myndigheder sig magten over Adyge Hasa og indplacerede Kremlvenlige folk på de ledende poster, hvorefter organisationen har været betydelig mere passiv. På det seneste er der opstået en uformel ungdomsgruppering inden for Adyge Hasa, som er begyndt at udfordre ledelsen. En ungdomsaktivist herfra blev skudt i KTR i foråret 2010 - formodentlig som en konsekvens af magtkampen mellem tjerkessere og karatjaier i republikken.

Gennem de seneste ti år har nye præsidenter afløst dem fra 1990'erne, som ofte var overlevere fra sovjettiden. De nye er udpeget fra Kreml og har ofte været succesfulde forretningsfolk, som er blevet mere eller mindre tvunget til at acceptere posten. De lokale befolkninger har generelt accepteret disse personer pga. deres forretningsmæssige succes og deres generelt moderne tilgang til bekæmpelse af korruption, revitalisering af økonomien etc. Præsident Arsen Kanokov i Karbardien-Balkarien er etnisk tjerkesser og havde før sin udnævnelse skænket en ny moske til hovedstaden Naltjik og har siden personligt finansieret opførelsen af en ny central kirke i byen. Den øgede politiske indflydelse, som de nordkaukasiske folk har opnået lokalt - bl.a. i takt med, at andelen af etniske russere er faldet - er fra Kremls side kontrolleret via en stor rolle til lokalafdelinger af Putins parti, Forenet Rusland.

I 2005 kom det til voldelige sammenstød mellem islamister og politi i Naltjik, hvilket kom til at koste mere end hundrede unge fra KBR livet i en aktion, hvor myndighederne - som i andre såkaldte antiterroraktioner i Rusland - valgte en aktionsform, som medførte uforholdsmæssigt mange ofre. Der er i KBR en udbredt opfattelse af disse unge som en gruppe, der havde vendt sig til religion i frustration over arbejdsløshed og manglende fremtidsperspektiver. I mangel af andre mulig- 
heder og ikke nødvendigvis kun som udtryk for en stærk islamistisk tendens.

\section{Balkarer, karatjaier og russere}

Der har siden 1991 været megen rivaliseren og mange konflikter mellem de etniske grupper om politisk indflydelse i de tre republikker. På det seneste har der i 2010 været udbrud af vold, demonstrationer og drab i KTR, hvor en tjerkessisk ungdomsaktivist og en tjerkessisk kandidat til ministerpræsidentposten blev dræbt. Begge drab har forbindelse til den konflikt, der er opstået efter at den karatjaiske præsident udpegede en etnisk russer til regeringsleder, på trods af tradition for at denne post går til en tjerkesser. Khloponin, lederen af den nye føderale region Nordkaukasus, pålagde efterfølgende præsidenten at udpege en tjerkesser til posten.

I efteråret 2009 kom det til en ny konflikt mellem titelnationerne i KBR efter et overraskende forslag fra parlamentet om permanent at overføre de græsningsarealer i det kabardiske lavland til balkarske kommuner. Reaktionen var stærke protester fra kabardiske organisationer, som for første gang alle var samlede bag protesten. Præsidenten har da heller ikke godkendt forslag, som næppe kan gennemføres. Men det viste, hvor sensitive også territoriale spørgsmål kan være. Hver gang der har været optræk til den type kon- flikter, har balkarske foreninger luftet ønsket om etableringen af en selvstændig balkarsk republik. I Naltjik er der bygget et flot museum til mindet om balkarernes deportation til Centralasien fra 1944 til 1957 hvor de efter hjemkomsten blev tvunget til at bosætte sig i nye landsbyer langs floderne i stedet for de hidtidige landsbyer i de karakteristiske kaukasiske bjergterrasser, som nu henligger som ruiner.

I midten af 00'erne lød der gennem en periode stærke krav i Rusland om opløsning af Adygeja (AR) og indlemmelse af republikken i naboregionen Krasnodar, som geografisk fuldstændig omslutter AR. Bl.a. en række kosakorganisationer og pro-russiske organisationer promoverede aktivt opløsningen. Dette medførte skarpe reaktioner fra de tjerkessiske ledere i AR suppleret af stærke protester fra diasporaen - og forslaget endte med at blive taget af bordet efter involvering af centralmagten i Moskva.

Regeringen i Krasnodar Regionen har gennem mange år været præget af xenofobi, med mange negative referencer til muslimer og jøder. Som et paradoks kan nævnes, at regionen samtidig har været i stand til at modtage store summer i økonomisk støtte til genrejsning af især landbrug og fødevareproduktion fra EU-budgetter - noget som de etnisk-definerede naborepublikker i Nordkaukasus ikke har været i stand til at opnå på trods af større behov og på trods 
af, at denne form for støtte kunne fremme fredelig sameksistens.

\section{Diasporaen siden 1991}

I Tyrkiet har tjerkesserne indtil for ti år siden primært haft mulighed for at etablere kulturelle foreninger, og disse har i vid udstrækning samarbejdet med sovjetiske og russiske myndigheder, som i dag stadig har stor indflydelse på disse foreninger. Liberaliseringen mht. etniske minoriteters ret til at organisere og ytre sig har gennem de seneste ti år ført til dannelsen af adskillige nye organisationer, som definerer sig som politiske i forhold til de ældre, som stadig primært definerer sig som kulturelle. Det reelle billede er dog noget anderledes, da de alle må siges at bidrage til en generel politisering af 'den tjerkessiske sag'.

Fælles for stort set alle de nyere organisationer er, at de som første prioritet har haft at informere og bevidstgøre tjerkessere om deres historie og identitet, bl.a. fordi det i mange år var officielt forbudt at beskæftige sig med det, og fordi der har været en udbredt skam forbundet med eksileringen fra hjemlandet. Så historien har ofte været tabuiseret i hjemmene på trods af, at man boede i tjerkessiske landsbyer og talte tjerkessisk i hverdagen. Man er i flere landsbyer i dag i gang med at etablere museer til at råde bod på denne situation.

De fleste tjerkessiske aktivister i
Tyrkiet nævner det truende tab af det tjerkessiske sprog som en motiverende bekymring. Efter at man gennem syv generationer i eksil har været i stand til at fastholde sproget, er man nu i løbet af en generation ved at miste det i takt med den stigende urbaniserings- og uddannelsesgrad. Men frygten for en forestående fuld assimilering har fået mange til at blive aktive i organisationerne.

Folklore, musik og dans er stadig det vigtigste samlende element for de fleste tjerkessere. Men især et stigende antal unge, som lærer hinanden at kende på uddannelsesinstitutionerne og via internettet, er ved at ændre lidt på dette billede. Arbejdet internationaliseres i stigende grad, så der nu løbende er kontakter og koordinering.

Til gengæld går det stadig trægt med at samarbejde med tjerkessiske organisationer i hjemlandet og kontakterne er relativt få. Nogle organisationer er dog i stand til at samarbejde med mere uskyldigt udseende institutioner fx om forskningsbaserede analyser og publikationer også selvom disse både kan indgå $\mathrm{i}$ det interne arbejde mht. at bevidstgøre flere tjerkessere om deres historie og identitet og udgøre baggrundsmateriale i ansøgninger om anerkendelse af deres eksil som et folkemord.

Frygt for det russiske efterretningsvæsen har i vid udstrækning skabt splid og mistænksomhed i 
diasporaen, da mange af de personer og firmaer, der har aktivt samarbejde med Nordkaukasus, anses for at være russiske agenter eller informanter.

Det gradvise øgede politisering af de nyere organisationer gør sig også gældende i de øvrige diasporalande, hvilket vil blive illustreret i det følgende.

\section{Civilsamfund og digital diaspora}

Tjerkesserne er i disse år i fuld gang med at overskride den 'digital splittelse', som især har gjort sig gældende i Nordkaukasus med begrænset adgang til internettet, med stærk kontrol med servere og monitorering af aktivitet fra efterretningsvæsenets side. Det er ikke i længden muligt for myndighederne at opretholde disse tiltag, og samtidig er en ny generation af unge i Rusland bevidste om internettets muligheder.

Og mange tøver ikke med at kaste sig ud i aktiviteter, som den tidligere generation ikke turde af frygt for myndighederne. Der er dog stadig en tendens til, at etniske mindretal som tjerkesserne er lidt påpasselige, hvilket bl.a. fremgår af, at de efterhånden mange blogs om problemer med de mange byggeprojekter op til OL i Sotji.

En ny generation er i fuld gang med at reformere civilsamfundet $\mathrm{i}$ Rusland nedefra, hvilket sker samtidig med, at Rusland opnår meget lave placeringer i de årlige analyser af pressefrihed, minoritetsbeskyttelse og menneskerettigheder blandt alverdens lande.

Også i Tyrkiet har man været ramt af lignende og dog forskellige forsinkelsesfaktorer mht. civilsamfundsudvikling og fri benyttelse af internettet, men i dag florerer der blandt tjerkesserne en stærk internetbaseret og stadig mere politisk diskussion.

Gennem de senere år er der sket en veritabel eksplosion i antallet af tjerkessiske hjemmesider og tjerkessisk brug af sociale hjemmesider som Facebook, Twitter og YouTube. Der produceres således et tjerkessisk indhold af et omfang, som langt overstiger 1990'ernes. Via links opnår disse output en potentielt mangedoblet udbredelse i sammenligning med 1990'ernes output.

Der er dog stadig en tendens til sproglig opsplitning, hvor russisk bruges i Rusland, tyrkisk i Tyrkiet og blandt diasporaen i Europa og arabisk i Mellemøsten og Nordamerika. På det seneste har der været en stigende tendens til at søge at overskride de sproglige barrierer ved at oversætte hjemmesider til flere forskellige sprog, hvor engelsk har fået en stigende betydning som nyt fællessprog.

\section{Kampen for anerkendelse}

Fælles for stort set alle tjerkessiske organisationer - hvad enten de prioriterer at promovere musik og dans 
eller er eksplicit politiske - er ønsket om igen at etablere tjerkesserne som en synlig gruppe med egen identitet og historie. Dette arbejde retter sig både internt mod tjerkessere og mod omverdenen, hvor tjerkesserne enten er ukendte eller efter den russiske kolonisering endt med at forsvinde ud af alverdens historiebøger.

Kampen for synlighed og anerkendelse har fået mange forskellige udtryk og har også medført intern splittelse mellem de kulturelt og de politisk orienterede organisationer. I Tyrkiet såvel som i flere af de andre diasporalande er mange af de aktive personer i organisationerne motiveret af en blanding af den historiske uretfærdighed, som mange først for nylig er blevet klar over, da dette ofte har været et ikke-emne i tjerkessiske hjem, samt af frygten for den endelige assimilering inden for en overskuelig årrække, bl.a. som en konsekvens af at sproget i løbet af en generation er ved at forsvinde.

Efter Sovjetunionens sammenbrud i 1991 blev der i de tre her omtalte nordkaukasiske republikker publiceret og oversat en lang række nutidige og historiske værker - fra Rusland såvel som fra udlandet, som hidtil ikke havde været tilladte. Nye medier skrev på tjerkessisk og anvendte tjerkessisk sprog i radio og TV. Blade og aviser bragte lange serier om tjerkessisk historie og identitet. Kunstnere, intellektuelle og forskningsinstitutioner i de tre re- publikker deltog flittigt i denne proces. Blandt diasporaen fandt en tilsvarende proces sted, men den var lidt længere om at komme i gang bl.a. fordi der i Tyrkiet først i 00'erne er kommet nye åbninger for etniske grupper og civilsamfund.

Størstedelen af denne indsats repræsenterede et opgør med tsaristisk og sovjetisk historieskrivning, og mange deltagere var motiveret af muligheden for endelig at få sandheden om Tjerkessiens skæbne i 1800-tallet frem i lyset.

\section{Tilbageslag under Putin}

Disse processer blev på flere niveauer bragt til ophør i Vladimir Putins præsidenttid. Organisationer og medier kunne ikke længere frit formulere og promovere egne dagsordner. I forlængelse heraf blev også historieskrivningen strammet op til primært at promovere russisk patriotisme, hvilket skete i delvis modsætning de mange nordkaukasiske opgør imod Stalintidens overgreb mod regionens folkeslag. Storslåede officielle fejringer af den frivillige union mellem tjerkesserne og Rusland blev i 2007 gennemført med store budgetter på trods af, at man ti år tidligere via en historikerkommission bestående af både russere og kaukasiere var nået frem til, at betegnelsen 'frivillighed' ikke var dækkende, og fejringen dengang blev aflyst. Nu blev der bl.a. opført en stor triumfbue - a la den i Paris - cen- 
tralt i Naltjik, hovedstaden i KBR.

På trods af den officielle russiske holdning til historieskrivningen om relationen mellem Rusland og tjerkesserne kan der findes adskillige eksempler, som direkte modsiger den officielle version. Dette inkluderer fx store encyklopædier over tjerkessisk historie og identitet - ofte fremstillet i samarbejde mellem nordkaukasiske og diaspora-historikere, endda ofte suppleret af russiske specialister. Men den form for viden og aktivitet udfolder sig ofte $\mathrm{i}$ mere snævre akademiske faghistoriske kredse og publiceres lokalt i bøger, som ikke kommer frem til en større offentlighed.

Den største fælles internationale succes blandt tjerkesserne er uden tvivl institutionaliseringen af mindearrangementer hvert år den 21. maj, hvilket også markeres officielt i de nordkaukasiske republikker.

21. maj som mindedag for fordrivelsen har samlet alle de tjerkessiske organisationer. Men i 2010 er enheden blevet udfordret af ungdomsorganisationen Caucasian Forum, som bevidst planlagde demonstrationer flere steder i Tyrkiet samtidig med, at fællesorganisationen for de kulturelle foreninger, Kaffed, afholdt deres traditionelle ceremoni i Kefken ved Sortehavskysten, hvor fordrevne tjerkessere i 1864 overlevede i klippehuler. Dette er også udtryk for en øget politisering af 'den tjerkessiske sag', bl.a. fordi de formåede at få en række andre organisationer til at bakke op omkring demonstrationen. Aktionen - som i øvrigt fandt sted i koordination med lignende aktioner i en række andre diasporalande - markerer således også en ny polarisering mellem de kulturelt- og de politisk orienterede organisationer.

\section{Krav om anerkendelse af folkemord}

I 2006 fik en række tjerkessiske organisationer under ledelse af den nye nordkaukasiske organisation Circassian Congress afslag fra Ruslands parlament på en anmodning om anerkendelse af den tjerkessiske fordrivelse fra Nordkaukasus som forsøg på folkemord. I øvrigt med en lidt kryptisk reference til, at kun overgreb begået under den sovjetiske periode kunne tages i betragtning. Anmodningen blev herefter videresendt til Europa-Parlamentet og Europarådet, hvor den efterfølgende er indgået i de løbende konsulteringer med Rusland om minoritetsrettigheder mv.

I 2010 genfremsendte Circassian Congress - denne gang i fællesskab med endnu flere diasporaorganisationer og med yderligere dokumentationsmateriale fra diverse arkivstudier - en ny anmodning om anerkendelse af folkemord, men denne gang kun henvendt til de formelle europæiske institutioner. De sidste ledende figurer i Circassian Congress har i 2010 måttet forlade Rusland, efter at de i længere tid har le- 
vet med trusler fra især det russiske efterretningsvæsen. Flere havde i forvejen sendt deres børn og familier ud af landet af frygt for deres sikkerhed. De to drab i KTR i 2010 medvirkede til at forstærke denne beslutning.

\section{Protest $\bmod$ OL i Sotji}

Som nævnt udgør både Sotji og Krasnaja Poljana - de to vigtigste lokaliteter for OL i 2014 - i så høj grad centrale lokaliteter i den tjerkessiske historie, at OL er kommet til at fungere som et samlingspunkt for mange tjerkessere og ydermere som en form for øjenåbner i forhold til tjerkessisk identitet blandt mange tjerkessere, som ellers nærmest har mistet deres tjerkessiske identet. OL er for mange diasporaorganisationer en løftestang, som i de næste år vil give dem omtale og synlighed.

På det seneste har både den ellers Kreml-venlige organisation Adyge Hasa i AR og parlamentet i AR foreslået inkluderingen af et tjerkessisk kulturelt element i olympiaden og dens ceremonier, som det er set med andre oprindelige befolkningsgrupper i forbindelse med OL i bl.a. Sydney, Atlanta og Vancouver.

Der er kommet en lille officiel åbning over for tjerkesserne i forbindelse med OL i Sotji. Det er vedtaget at lave en ny skulptur ved lufthavnen, hvor en tjerkesser og en kosak (formodentlig begge iklædt den klassiske tjerkeska-dragt) rækker hinanden hånden. På klassisk sovjetisk maner. Den form for kreativ historiefortolkning bryder de lokale tjerkessere sig bestemt ikke om.

For nogle år siden etablerede tjerkessiske aktivister i Tyrkiet en protest-hjemmeside, som de kaldte olympicgenocide.org. I 2010 er initiativet taget op igen, nu med en formel opbakning fra ni organisationer i en lang række lande, dog ikke Rusland. Den såkaldte 'No Sochi'-kampagne inkluderer hjemmesiden nosochi2014.com, facebook- og twittersider, youtube-indslag etc. Kampagnen omfatter demonstrationer og manifestationer, som set i forbindelse med vinter-OL i Vancouver og senest i forbindelse med 21. maj-arrangementer, hvor store bannere insisterer på 'No Sochi on Land of Genocide'. Kampagnen skaber således ikke blot et link til kampagnen om anerkendelse af folkemord, men er ligeledes også en måde at søge historisk rehabilitering på.

\section{Fælles-tjerkessisk republik?}

Kravet om etablering af en fælles tjerkessisk republik i Nordkaukasus, som skulle omfatte alle tjerkessiske områder i de tre omtalte republikker, er på det seneste blevet et centralt emne for adskillige tjerkessiske organisationer. Som noget nyt inkluderer de flere af de Kreml-kontrollerede organisationer og markerer ydermere en ny form for enighed på tværs af grænserne mellem de tre re- 
publikker. Hidtil har samarbejde på tværs været minimalt, da organisationernes aktiviteter ofte har rettet sig mod ledelsen i deres hjemrepublik. Etableringen af den nye føderale russiske region Nordkaukasus bliver af nogle tjerkessere anset for et forsøg på at hindre skabelsen af en ny tjerkessisk republik, da AR ikke indgår i regionen og Sortehavskysten heller ikke.

I KTR har konflikten omkring udpegelsen af en ny regeringsleder i foråret 2010 øget distancen mellem de to titularnationaliteter, hvilket har øget tjerkessiske krav om etableringen af et tjerkessisk distrikt, som ikke længere skulle være under kontrol af KTR-ledelsen. Dette krav er forstærket med de to tidligere nævnte drab i republikken i foråret 2010.

I forlængelse af ideen om en fælles tjerkessisk republik kan det nævnes, at de tjerkessiske organisationer i 2010 gennemfører en kampagne for, at tjerkesserne i den kommende folketælling ikke skal acceptere at være opsplittet i en række undergrupperinger, og de opfordres derfor alle til at angive sig selv etnisk som 'tjerkesser'.

\section{Repatriering}

Ønsket om promovering af repatriering fra diasporaen har været på dagsordenen lige siden Sovjetunionens sammenbrud i 1991. Der var oprindelig store forventninger til repatriering, men det er gået meget langsomt. Hidtil er det kun lykkedes for under to tusind fra diasporaen at flytte til Nordkaukasus.

Den eneste større gruppe, der er vendt tilbage, er tjekessere fra en landsby fra Kosovo, som måtte flygte i forbindelse med krigshandlingerne i 1999. Efter en kampagne, hvor bl.a. kaukasiske organisationer i Istanbul var aktive, kunne de i 2002 flytte ind i nye huse i en nyopført landsby i Adygeja. Deres succesfulde tilbagevenden førte i 2006 til forslag om repatriering af diasporaen i Irak, som også var kommet i klemme mellem forskellige grupperinger i forbindelse med krigen i Irak. De blev besøgt af diasporarepræsentanter, men forslaget om repatriering til Kaukasus løb ud i sandet.

At befolkningspolitik ofte er konfliktfyldt blev bl.a. illustreret, da parlamentet i KBR vedtog en repatrieringslov i 2001, hvilket førte til stærke protester fra balkarer og russere, med beskyldninger mod kabarderne om at være ude på at ændre den 'demografiske balance' ved 'import' af etnisk beslægtede folk. Hvilket ikke var helt ved siden af, da der er langt flere kabardere end balkarer i den kaukasiske diaspora. Loven blev tre år senere ophævet af Moskva for at være i strid med den russiske forfatning.

Det faldende befolkningstal i Rusland har medført mange diskussioner af fremtidige scenarier - inklusive skræmmebilleder blandt russiske politikere og medier. I forlængelse 
heraf blev den Anden Verdenskongres for Landsmænd (compatriots) fra Rusland i 2006 afholdt i Sankt Petersborg med høj profil, inklusive deltagelse af daværende præsident Putin og udenrigsminister Sergej Lavrov. Også tjerkessiske repræsentanter fra diasporaorganisationer var til stede. I forlængelse heraf blev der udarbejdet et nyt føderalt program for repatriering af landsmænd, hvilket førte til forsigtige forventninger blandt tjerkessiske politikere og organisationer. Men igen blev deres forventninger skuffet, da de ikke blev 'prioriteret' i første runde - i modsætning til etniske russere.

Putin var i 2007 på en rundrejse i Mellemøsten, hvor de to etnisk tjerkessiske præsidenter (Arsen Kanokov i Karbardinien-Balkarien og Aslan Tkhakusjinov i Adygeja) fra Nordkaukasus deltog med nye forhåbninger om reelle diskussioner af muligheder for repatriering. Dog viste det sig hurtigt, at Putin primært var interesseret i diasporaens penge frem for deres kroppe, da han kun opfordrede diasporaen til at investere i Rusland og i Nordkaukasus, ikke at flytte dertil. De to tjerkessiske præsidenter blev fanget mellem diasporaens fremsættelse af ønsker om konkrete repatrieringsprogrammer (og anerkendelse af det tjerkessiske folkemord) og den officielle russiske holdning.

På det seneste har afskaffelsen af visumtvangen mellem Rusland og Tyrkiet muliggjort et øget samkvem mellem tjerkessere i hjemlandet og $\mathrm{i}$ diasporaen. Det kan vise sig at være første skridt i retning af øget samkvem, men for at øge den konkrete repatriering kræves der en række yderligere tiltag. Foreløbig er der kun i Adygeja et program for promovering og støtte til repatriering, men resultaterne er stadig begrænsede. Blandt forhindringerne for repatriering kan nævnes manglende reel politisk opbakning i republikkernes regeringer og et stort og uigennemskueligt bureaukrati omkring registrering, opholdstilladelse, tilladelse til at skabe egen virksomhed etc.

\section{Efter krigen i Georgien}

I marts 2010 blev der i Georgien afholdt en konference om tjerkesserne under titlen 'Hidden nations, enduring crimes', som mundede ud $i$ en resolution, der opfordrede Georgiens parlament til som det første FN-land at anerkende det tjerkessiske folkemord. Konferencen blev afholdt med støtte fra den georgiske stat og gennemført i samarbejde med den ofte Ruslands-kritiske amerikanske tænketank Jamestown Foundation. Repræsentanter fra organisationen Circassian Congress i Nordkaukasus fik ikke udrejsetilladelse af de russiske myndigheder og blev i stedet repræsenteret af flygtninge fra USA. De i diasporasammenhæng toneangivende tyrkiske organisationer afstod fra at deltage, 
da de ikke ønskede at blive inddraget i georgisk udenrigspolitik - især på baggrund af deres stærke solidaritet med abkhaserne gennem mange år. Som en konsekvens af denne konference blev en diasporakonference i Jordan i maj måned aflyst efter pres fra russisk side.

Hændelserne omkring krigen mellem Rusland og Georgien, anerkendelsen af Abkhasien og vinterolympiaden i Sotji i 2014 er således ved at give tjerkesserne en rolle i det geopolitiske magtspil i Kaukasusregionen. Dette vil øge deres synlighed, og det vil kunne styrke fællesskabsfølelsen blandt tjerkesserne. Men en sejr for synligheden kan samtidig sagtens betyde et nederlag på de øvrige parametre, fx skabelsen af en fælles republik og øget repatriering. Tjerkessernes geopolitiske platform er skrøbelig og deres alliancemuligheder begrænsede - på trods af de nye åbninger.

Alligevel er der ingen tvivl om, at tjerkesserne her små tyve år efter Sovjetunionens sammenbrud på mange måder befinder sig ved en korsvej. På trods af politisering, splittelse og marginalisering peger meget i retning af øget fremtidigt samarbejde på tværs af grænser. Også selvom den eneste Kreml-kritiske organisation i Nordkaukasus er blevet tvunget i knæ, og de ledende medlemmer gået i eksil. Den tendens til politisering, som ses blandt diasporaorganisationer, ligger og ulmer under overfladen i Nordkaukasus.

Mange tjerkessere er stadig skræmte af det tjetjenske eksempel og holder sig afventende. Men unge aktivister i regionen kan i stigende grad forventes at fortsætte med at tage nye initiativer, inklusive inddragelsen af internettet til diskussion, informationsspredning, mobilisering og kontakt til diasporaen. Forhåbentlig også uden at frustration fører til dannelse af voldelige grupperinger og voldshandlinger.

Civilsamfundet bliver i Rusland holdt i kort snor, men i det øjeblik der løsnes på båndet, kan det ikke udelukkes, at de lokale tjerkessiske aktører kan få nye alliancepartnere. Bl.a. fordi en del civilsamfundsaktører og forskere i Rusland har luftet utilfredshed med det manglende opgør med den samlede fortid altså ikke blot den sovjetiske - men også den blodige imperiale kolonisering af randområder. Sådanne processer er under udfoldelse med forskellige grader af politisk opbakning i flere post-sovjetiske lande, hvilket på længere sigt kan få indflydelse i Rusland og i Nordkaukasus.

Lars Funch Hansen er videnskabelig assistent $i$ komparative kulturstudier ved Institut for Tverkulturelle og Regionale Studier, Københavns Universitet. 